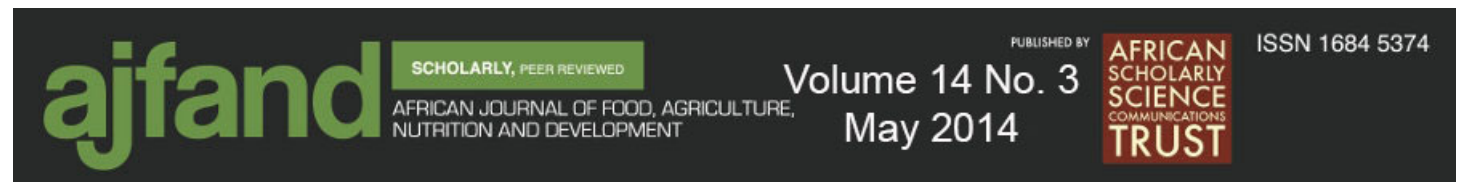

\title{
PESTICIDE CONTAMINATION OF THE DRIDJI COTTON PLANTATION AREA IN THE REPUBLIC OF BÉNIN
}

Yehouenou A Pazou E ${ }^{1}$, Glin $L^{2}$, Vodouhe $D^{3}$, Fanou $\mathrm{J}^{3}$, Babadankpodji AP ${ }^{3}$, Dassou $S^{4}$, Vodouhe $S^{4}$, van Hattum $B^{5}$, Swart $K^{5}$ and CAM van Gestel ${ }^{5^{*}}$

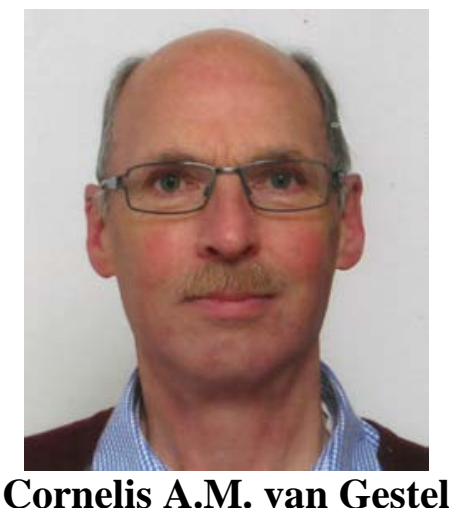

*Corresponding author email: kees.van.gestel@vu.nl

1 Ecole Polytechnique d'Abomey-Calavi, Département de Génie de l'Environnement, Laboratoire de Recherche en Biologie Appliquée (LARBA), Université d'Abomey-Calavi, 01 BP 2009 Cotonou, Bénin

2 Organization for the Promotion of Organic Farming (OBEPAB), 02 BP 8033 Cotonou, Bénin

3 Faculty of Agricultural Sciences, University of Abomey, Department of Economics, Socio-Anthropology and Communication (deactivated), BP 526 Abomey, Bénin

4 Faculté des Sciences de la Santé, Université d’Abomey-Calavi, BP 188 Cotonou, Bénin

5 Faculty of Earth and Life Sciences, VU University, De Boelelaan 1085, 1081 HV Amsterdam, The Netherlands 


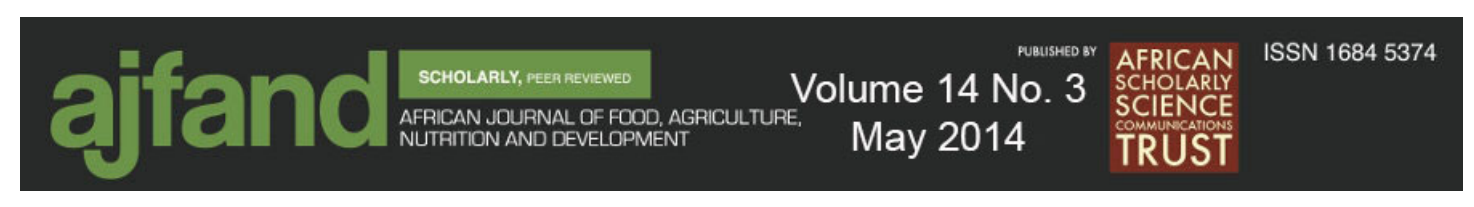

\begin{abstract}
Pesticides used for cotton production and pest control in the growing of food crops such as beans, maize and vegetables eventually may not only end up on the crops, but also in soil and surface water. As a consequence, aquatic organisms and humans consuming crops may experience pesticide exposure. This also is the case in developing countries in Africa, where pesticide use sometimes is less controlled and includes the use of older organochlorinated products. This study assessed the public health risk due to pesticide exposure along the Kiti River in the Dridji cotton-growing area in the Republic of Bénin. Aquatic organisms from the Kiti River and vegetable plants commonly consumed by the local people were analyzed for residues of organochlorinated pesticides. Kiti River sediment contained metabolites of DDT with levels up to $5.14 \mu \mathrm{g} / \mathrm{kg}$ dry weight. In fish, crabs and amphibians collected from the Kiti River DDT-like compounds and $\alpha$-endosulfan reached levels up to $403 \mathrm{ng} / \mathrm{g}$ lipid. Leaves from beans grown in the river floodplain and consumed by the local population were contaminated with 10 pesticides including DDT-like compounds, $\alpha$ endosulfan, dieldrin, lindane, hexachlorobenzene and heptachlor. Sum DDT concentrations in the bean leaves ranged between 274 and $1351 \mu \mathrm{g} / \mathrm{kg}$ dry weight, while these vegetables also contained endosulfan (23-210 $\mu \mathrm{g} / \mathrm{kg}$ dry weight), dieldrin $(<9-32 \mu \mathrm{g} / \mathrm{kg}$ dry weight) and lindane $(<6-90 \mu \mathrm{g} / \mathrm{kg}$ dry weight $)$ in high concentrations. To assess the risk to public health, pesticide intake by fish and vegetable consumption was estimated and compared with Tolerable Daily Intake (TDI) values reported by the World Health Organization. This comparison showed that fish consumption does not pose a risk for public health, but that consuming bean leaves as vegetables may lead to exceeding of TDI values. It is concluded that pesticide contamination in the Dridji cotton production area poses a risk to public health.
\end{abstract}

Key words: Pesticides, agriculture, humans, risk, food 


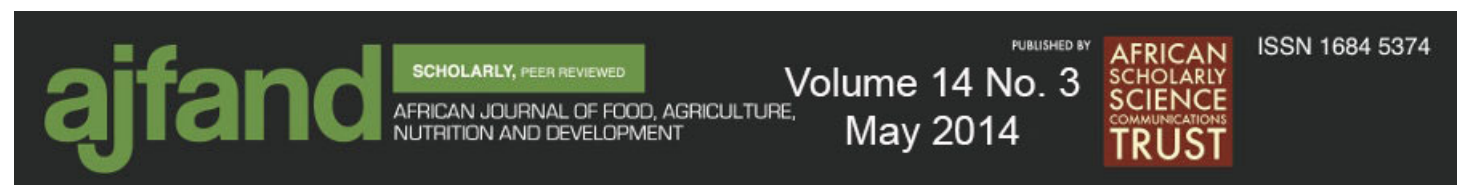

\section{INTRODUCTION}

To increase agricultural production many synthetic chemicals (pesticides and fertilizers) are used for pest control, crop protection and land fertilization. In the Republic of Bénin, pesticides are used not only for cotton production but also for pest control in the growing of food crops such as beans, maize and vegetables [1]. Pesticides may not only end up on the crops, but also in soil and surface water [1-3]. When pesticide contamination of surface water occurs, biota living in the sediment and water may become exposed [3]. As a consequence, aquatic organisms and humans consuming crops may experience pesticide exposure.

Pesticide use also is high in the Dridji area in the Republic of Bénin, where cotton production is a major activity. Dridji is located in the Province of Zou in Central Bénin. The Kiti River is source of drinking water and food (fish and other aquatic species) for people living in the area. A previous study showed that water from the Kiti River contained high nitrite levels due to fertilizer use for cotton production (Yehouenou A. Pazou et al., unpublished). In addition to cotton production, vegetable growing for human consumption is another important activity in the Dridji area. This study therefore had two aims. First aim was to determine the level of pesticide contamination in a cotton production area by analysing sediment, water, aquatic species and vegetables. Second aim was to assess public health risk of pesticide exposure by comparing the estimated pesticide intake by fish and vegetable consumption with Tolerable Daily Intake levels developed by the World Health Organization [4].

\section{MATERIALS AND METHODS}

The study was part of the Ecohealth project in which an ecosystem approach, based on trans-disciplinarily, participation, gender and ethics was applied by an interdisciplinary team of researchers composed of biologists, environmentalists, agronomists, doctors and sociologists. Water, sediment and aquatic organisms from the Kiti River as well as bean leaves grown near the river were sampled and analyzed for pesticide residues.

\section{Study area}

Dridji village is located in Central Bénin, Province of Zou. It is composed of nine settlings: Ahoyèmè, Asségon, Atchessingon, Daanonkpota, Dridji Centre, Kindogon, Kitigoudo, Lègbaholi and Tèzounkpa. The area has a sub-equatorial climate characterized by two rainy seasons. The village belongs to the agro-ecological zone located between the seventh and ninth degree of north latitude. It receives water from the rivers Kiti and Azoua, two tributaries of the Zou River. Figure 1 shows a map of the village indicating the different settlings. Sampling of water, sediment and aquatic organisms was from the Kiti River while bean leaves were collected from agricultural sites near two of the settlings. 

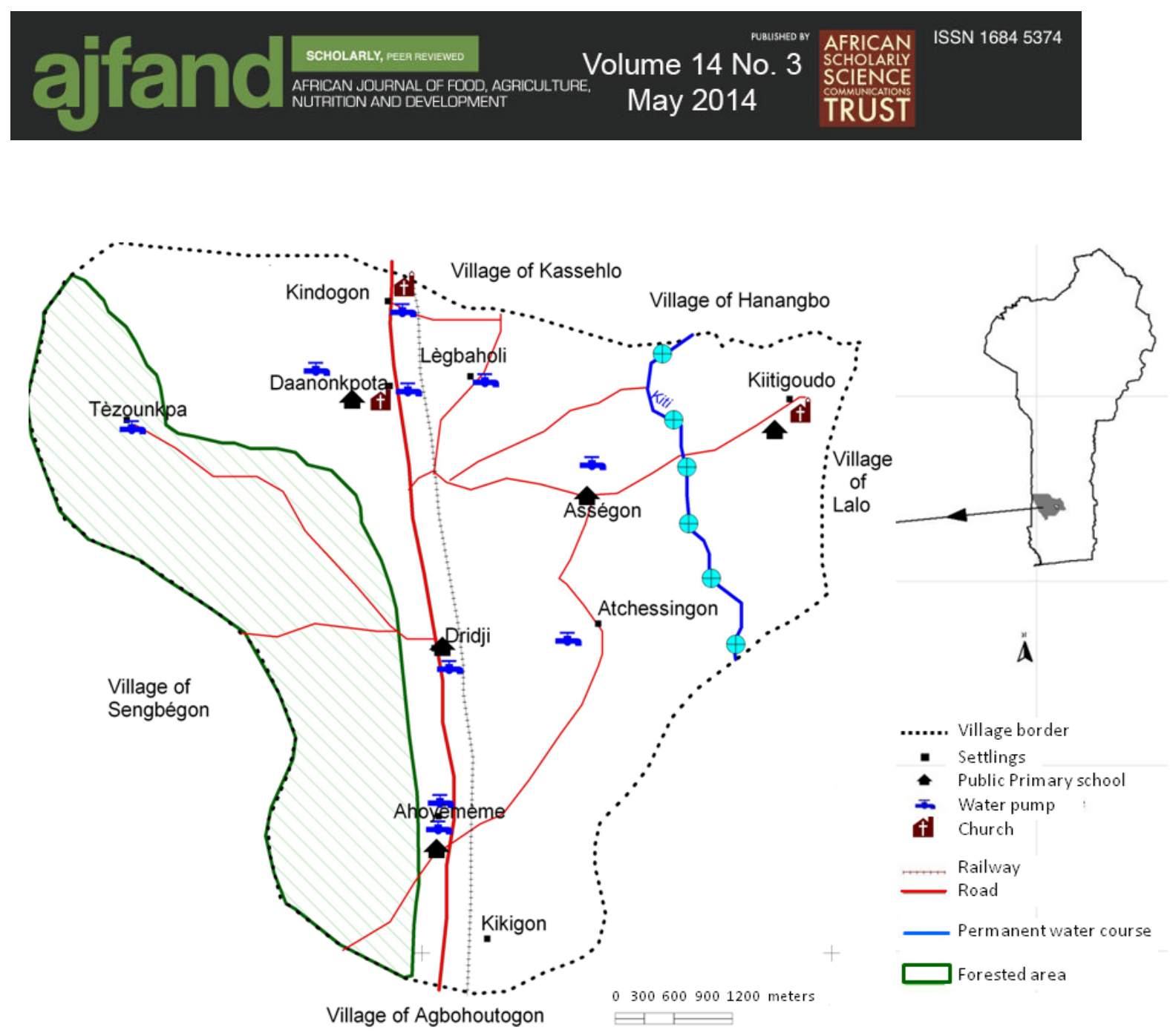

Figure 1: Location of the Dridja village and its settlings in the Republic of Bénin. The Kiti River was sampled for sediments and aquatic organisms, while bean leaves were sampled from areas near the settlings of Kindogon and Daanonkpota.

\section{Questionnaire}

An inventory of pesticide use in the Dridji area was conducted using a structural questionnaire, observation and focused group discussions among farmers according to gender in the nine villages of Dridji.

\section{Sampling}

Water sampling in the Kiti River was performed each month during a year. Water was collected with a 1-liter sterilized glass bottle directly immersed in the river. The water collected was transferred into a polystyrene bottle and placed in a cooler with ice.

Sediment samples were taken in 2002 at six locations along the Kiti River (DK1-6). Approximately $250 \mathrm{~g}$ samples of wet sediment were collected at a depth of 0 to $10 \mathrm{~cm}$ with a grab. Sediment samples were put in sterilised bottles placed in a cooler with ice and transported to the laboratory. Sediment samples were frozen, lyophilized and stored at $-20^{\circ} \mathrm{C}$ before analysis. 
Various aquatic species, including fish (Clarias gariepinus and Clarias ebriensis), amphibians (Bufo regularis, Xenopus muelleri) and crabs (Cardiosoma aramatum) were collected from the Kiti River in 2004, using a net. All organisms were weighted, dissected, frozen, lyophilized and stored at $-20^{\circ} \mathrm{C}$ before analysis

Beans leaves ready for consumption were collected in 2004 from the field at two villages, Danonkpota and Kindogon, in duplicate, washed, and dried at room temperature in the laboratory for a month. Next they were ground to powder before analysis.

All samples were transported to the Netherlands for analysis; sediments were analysed at VU University in Amsterdam, plants and aquatic organisms at the Hoogheemraadschap Hollands Noorderkwartier (HHNK) in Edam.

\section{Physical-chemical analysis of water and sediments}

Water $\mathrm{pH}$ was measured with a WTW $730 \mathrm{pH}$ meter, turbidity with a HACH 2100 AN turbidity meter, and conductivity with a WTW LF91 meter. Nitrite concentration in the water was measured by photometry using sulfanilic acid and $\alpha$-naphtylamine. Nitrate levels were measured with a HACH DR/4000U spectrophometer, using the sodium salicylate method.

Organic matter content of the sediment was determined as loss on ignition method upon burning the dried samples for 6 hours at $500{ }^{\circ} \mathrm{C}$. Sediment particle size distribution analyses were done with a Laser Particle Sizer A 22 following [5].

Total carbon and nitrogen concentrations in duplicate samples were measured by burning the dried samples in a stream of pure oxygen in combination with column chromatography with an Elementary Analyser (Carlo Erba Strumentazione model 1106). For calibration samples of 2,5-bis-(5-tert-butyl-benzoxazol-2-yl)-thiophene (BBOT) from Fluka, 14555, were used.

\section{Analysis of organochlorine pesticide residues}

Sediments were analysed at the Institute of Environmental Studies of the VU University in Amsterdam, the bean leaves and aquatic organisms in the certified laboratory of the Hoogheemraadschap Hollands Noorderkwartier (HHNK) in Edam.

All solvents as well as other chemicals used were of analytical grade quality (Merck, J.T. Baker) to ensure purity.

Sediment samples were extracted in an accelerated solvent extractor (ASE 200, Dionex, Sunnyvale, CA, USA) with $20 \mathrm{ml} \mathrm{n}$-hexane-acetone (9:1 V/V; Merck, Darmstadt, Germany). The extracts were placed on top of a column containing a small amount of glass wool at the bottom, covered with $3 \mathrm{~g}$ aluminium oxide 15\% (type Woelm, ICN, Fisher Scientific, Landsmeer, The Netherlands) deactivated with water and conditioned with $4 \mathrm{ml}$ petroleum ether-diethyl ether (95:5 V/V, Merck) before adding the concentrated extract. Petroleum ether-diethyl ether $(17 \mathrm{ml})$ was used to elute pesticides from the column. The extracts were concentrated to about $0.5 \mathrm{ml}$ under a gentle stream of nitrogen gas at $30{ }^{\circ} \mathrm{C}$. One $\mathrm{ml}$ isooctane was added to the 


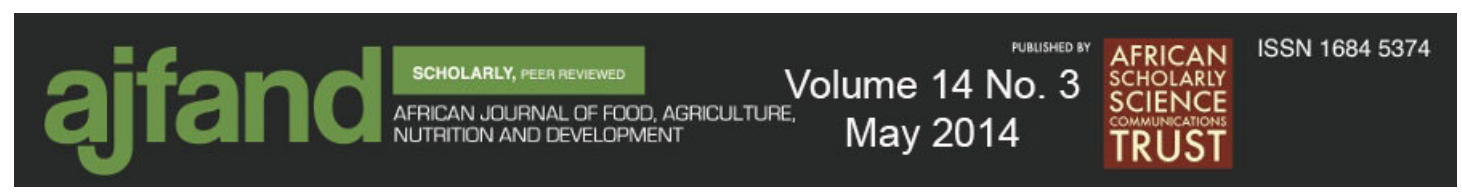

extracts that were again concentrated to $0.5 \mathrm{ml}$. The extracts were transferred into vials for automated analysis by gas chromatography with electron-capture detection (GC-ECD). The ECD response was calibrated using a standard containing 24 organochlorinated pesticides and 8 polychlorinated biphenyls (PCBs).

Chlorinated pesticides in sediment were determined by GC (Varian 3800, Walnut Creek, CA, USA) in combination with an auto sampler (Varian 8200), and an ECD (Varian EFC 13). ECD temperature was $300{ }^{\circ} \mathrm{C}$. Helium was used as the carrier gas with a flow rate of $1 \mathrm{ml} / \mathrm{min}$ and nitrogen make-up gas at a flow rate of $30 \mathrm{ml} / \mathrm{min}$. The injection volume was $3 \mu \mathrm{l}$ with a split-less injection mode. Organochlorine residue components were identified by comparing their retention times with those of the standard mixture of PCBs and organochlorinated pesticides. The calibration line of the standard was slightly quadratic for almost all compounds. The limit of detection for all pesticides including EDDT (pp'-DDE, op'-DDD, pp'-DDD' op'-DDT, pp'DDT) was $0.1 \mu \mathrm{g} / \mathrm{kg}$ for the sediment, the limit of quantification (LOQ) was 0.3 $\mu \mathrm{g} / \mathrm{kg}$ sediment.

The freeze-dried and lyophilised plant (5 g) and fish (2 g) samples were ground using a ceramic pestle and mortar. Samples were extracted with $200 \mathrm{ml}$ acetone by shaking for $10 \mathrm{~min}$, after which $20 \mathrm{ml}$ of a saturated sodium sulphite solution and $100 \mathrm{ml}$ petroleum ether were added. After shaking for $10 \mathrm{~min}$, the suspension was filtered over a paper filter and washed twice with $500 \mathrm{ml}$ deionized water to which $20 \mathrm{ml}$ sodium chloride solution was added. After washing, the petroleum ether fraction was dried with sodium sulphate and volume reduced evaporation in a Kuderna-Danish rotavapor at $75-80{ }^{\circ} \mathrm{C}$.

Lipid contents of the fish were obtained by weighing and drying $1 \mathrm{ml}$ of the extract.

For clean-up of the extract, a similar procedure was followed as described above, using an aluminium oxide column and elution with petroleum ether. A second cleanup step was included, using a column of deactivated silica gel, and elution with petroleum ether. The extracts were concentrated to $2.0 \mathrm{ml}$ under a gentle stream of nitrogen gas. Analysis took place by GC (Hewlett Packard 6890) with ECD, equipped with an autosampler Hewlett Packard injector 7673 and a Chrompack 8753 CP-Sil-8 CB column. Helium was used as the carrier gas, and organochlorine pesticides were identified by comparing their retention times with those of a standard mixture of PCBs and organochlorinated pesticides. For calibration purposes, PCB155, mirex and tetrachlorobenzene were used as internal standards, while also a reference material was analyzed.

The limit of detection for the organochlorinated pesticides including $\Sigma$ DDT (pp'DDE, op'-DDD, pp'-DDD' op'-DDT, pp'-DDT) was $0.3 \mu \mathrm{g} / \mathrm{kg}$ for the plant samples and $0.1 \mathrm{ng} / \mathrm{g}$ lipid for the fish. The limit of quantification was $0.6 \mu \mathrm{g} / \mathrm{kg}$ for plant samples and $0.3 \mathrm{ng} / \mathrm{g}$ lipid for the fish.

Quality assurance measures applied included rigorous contamination control procedures (strict washing and cleaning procedures), monitoring of blank levels of 


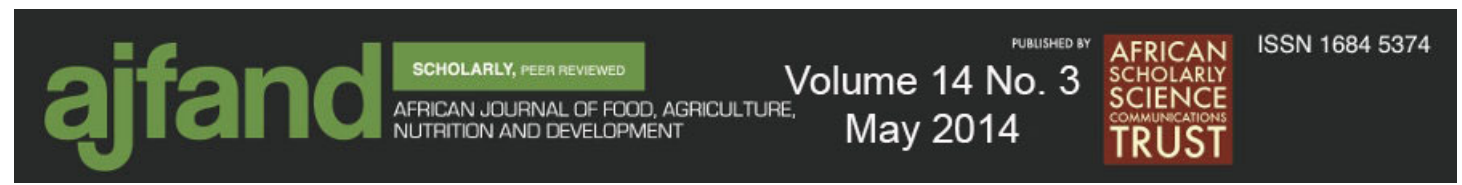

solvents, equipment and other materials, analysis of procedural blanks, recovery of spiked standards, monitoring of detector response and linearity, and analysis of a reference material. Recoveries of chlorinated pesticides in the reference material were between $80 \%$ and $110 \%$ of certified concentrations.

\section{Human health risk assessment}

To assess the risk of pesticide intake by the consumption of fish or other seafood, it was assumed that local people would eat one fish or one of the other aquatic organisms (amphibian, crab) per day. Based on this and using the measured pesticide concentrations, for each pesticide daily intake was estimated. Next, intake was normalized for an average human weighing $60 \mathrm{~kg}$. The estimated daily intake values were compared with the Tolerable Daily Intake (TDI) values reported by the WHO [4]. Assuming that all pesticides have a similar mode of action, the toxic unit approach was adopted to enable summing the risk of the different pesticides detected. A toxic unit was defined as the estimated intake of a pesticide by consuming fish or other aquatic organisms divided by its TDI.

For pesticide intake by consuming bean leaves, using the TDI values, and assuming an average human body weight of $60 \mathrm{~kg}$ and a consumption of $100 \mathrm{~g}$ dry weight of bean leaves, tolerated residue limits were estimated for each pesticide. Next, the measured pesticide levels were related to the tolerated residue limit to derive toxic units. The summed toxic unit combining the different pesticides was used as an indication of the risk.

In case the sum of the toxic units would approach or exceed the value of 1 , this would indicate a risk for the local population. By comparing the summed toxic units for fish, amphibians, crabs and bean leave consumption, it could also be assessed which food item posed the greatest risk for the local population in the cotton production area.

\section{RESULTS}

\section{Activities potentially affecting pesticide exposure}

In total, 1378 questionnaires were distributed among Dridji cotton producers. The response to the questionnaire showed that pesticides used in the Dridji area were mainly organochlorine, organophosphorous and pyrethroid insecticides. Endosulfanbased pesticides were applied to maize and beans to kill cereals pests and hair lice. Empty bottles of pesticides were recycled to buy oil from the market and to bring water to the fields.

From the questionnaires, it was learned that Dridji people practice several activities including agriculture (81\%), which represented the main activity. The main crops grown were maize, bean and cotton. Fishing was done by $8 \%$ of the population.

\section{Physical-chemical parameters of water}

Water $\mathrm{pH}$ was between 6.5 and 7.0. Turbidity of Kiti River water was very high (125 NTU), while conductivity was within the normal range (400 S/cm). Ammonium 


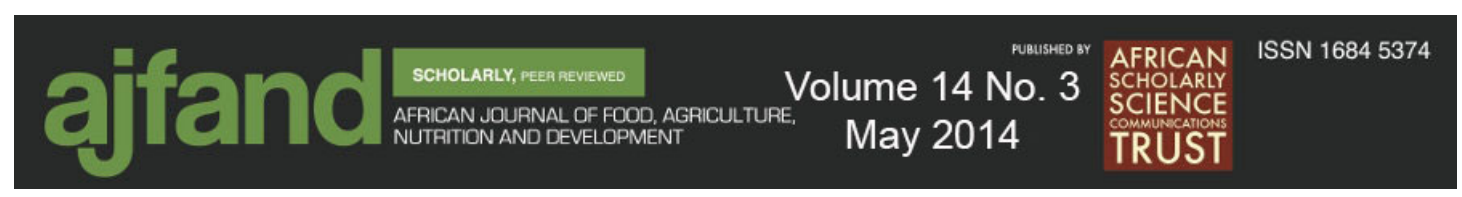

concentration was higher than the normal value for drinking water, which is between 0.05 and $0.5 \mathrm{mg} / \mathrm{L}$. Nitrite concentrations ranged between 0.01 and $0.1 \mathrm{mg} / \mathrm{L}$, which is slightly above the normal range.

\section{Sediment}

At the sampling sites DK1 and DK4 the dominant fraction in the sediment was coarse sand (Table 1), which shows that the flow rate of the Kiti River is not high. At the other sites, DK2, DK3, DK5 and DK6, silt content was high. The organic matter content of the sampled sediments generally was low (1.0-6.5\%), with highest levels measured at DK6.

Pesticides identified in sediments were pp'-DDE, pp'-DDT and $\alpha$-endosulfan (Table 2 ); concentrations of the latter however, did not exceed the detection limit. pp'-DDE levels in the Kiti River sediment varied from the detection limit to $2.1 \mu \mathrm{g} / \mathrm{kg}$ dry weight.

\section{Pesticide residues in aquatic species}

The fish species Clarias gariepinus and Clarias ebriensis, the amphibians Bufo regularis and Xenopus muelleri, and the crab Cardiosoma armatum collected in the Kiti River contained pp'-DDE, pp'-DDD, op'-DDT, pp'-DDT and $\alpha$ - endosulfan (Table 3). The pp'-DDE concentrations found in aquatic species varied from 23 to $403 \mathrm{ng} / \mathrm{g}$ lipid, while $\sum$ DDT levels ranged between 23 and $515 \mathrm{ng} / \mathrm{g}$ lipid. $\alpha$ Endosulfan was identified in all aquatic species collected in the Kiti River and ranged from 27 to $75 \mathrm{ng} / \mathrm{g}$ lipid.

\section{Pesticide residues in bean leaves}

All bean leaves were contaminated with op'-DDE, pp'-DDE, op'-DDD, pp'-DDD, op'-DDT, pp'-DDT. $\alpha$-endosulfan, dieldrin, lindane and hexachlorobenzene, with levels varying between locations in the same village (Table 4). $\Sigma$ DDT and $\alpha$ endosulfan levels in bean leaves collected from the Daanonkpota locations (mean 1035 and $158 \mu \mathrm{g} / \mathrm{kg}$, respectively) were higher than from the Kindogon locations (413 and $25.5 \mu \mathrm{g} / \mathrm{k}$, respectively).

\section{Risk assessment}

The estimated intakes of $\Sigma$ DDT and $\alpha$-endosulfan from fish consumption are shown in Table 5, These intakes were compared with Tolerably Daily Intakes. For all aquatic species, the sum of toxic units was far below 1.0, indicating risk of pesticide intake by fish consumption is low.

Risk assessment for pesticide intake by consumption of bean leaves is summarized in Table 6. At three out of the four sampling sites, pesticide concentrations in the bean leaves were close to the maximum tolerated levels with a sum TU of $0.33-0.88$; dieldrin contributed most to the risk. 


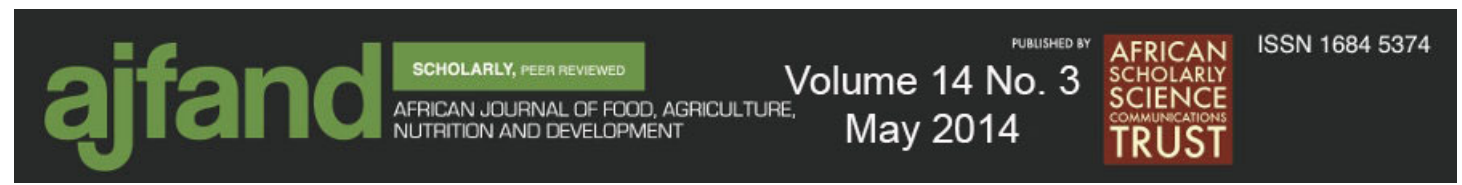

\section{DISCUSSION}

\section{Water quality and pesticides in sediment}

The very high turbidity of the Dridji River water might be due to the presence of debris from runoff, although this was not investigated in this study. Turbidity was 25 times the standard for drinking water, yet water is often consumed by local people without prior treatment. Ammonium and nitrate levels were slightly elevated and did exceed the normal values for drinking water. This probably is due to the excessive use of fertilizers in agriculture in the area. These results suggest that Dridji River water may not be suitable for consumption.

Compared to other locations along the Ouémé River, pesticide levels in sediment found in this study (Table 2) were higher than in the Donga $(0.55 \mu \mathrm{g} / \mathrm{kg} \mathrm{d}$.w.) and Kpassa areas $(0.51 \mu \mathrm{g} / \mathrm{kg}$ d.w. $)$ and also in the Beterou area $(0.15 \mu \mathrm{g} / \mathrm{kg} \mathrm{d.w.})$ [2]. pp'DDE levels in Kiti River sediment were lower than in sediments from the Yamuna River (3.45-72.2 $\mu \mathrm{g} / \mathrm{kg}$ d.w.) [6] and the Gomti River (14 $\mu \mathrm{g} / \mathrm{kg}$ d.w.) in India [7], and from Botsomtwi in Ghana [8] and Victoria Lake (0.13-2.7 $\mu \mathrm{g} / \mathrm{kg}$ d.w.) in Kenya [9]. The pp'-DDE levels in Kiti River sediment were higher than concentrations found in a tropical mangrove estuary (0.001-0.006 $\mu \mathrm{g} / \mathrm{kg}$ d.w.) in India [10]. pp'-DDT was detected in sediment at only one site along the Kiti River; the level detected at DK6 $(5.1 \mu \mathrm{g} / \mathrm{kg}$ d.w.) was higher than those in the Lowé and Beterou floodplain areas along the Ouémé River in the Republic of Bénin [2], but lower than in Yala/Nzoia sediment in Kenya (9.48 $\mu \mathrm{g} / \mathrm{kg}$ d.w.) [9]. In Kiti River sediments $\Sigma$ DDT was 0.8-5.1 $\mu \mathrm{g} / \mathrm{kg}$ d.w. The fact that DDT was present in detectable amounts in only one sample, while the more persistent metabolite DDE was found at several sampling sites suggests this insecticide has not recently been used in the area [8, 11, 12]. Residues found in this study, therefore, probably resulted from earlier use.

\section{Pesticide residues in aquatic species}

The fact that DDE levels in all organisms were much higher than those of the less persistent parent DDT (Table 3), suggests residues did not result from recent DDT use $[8,11,12]$. 5 DDT level quantified in Clarias gariepinus caught in the Kiti River (214 ng/g lipid) was lower than in the same species from Beterou (535 ng/g lipid), Bonou (1642 ng/g lipid), and Houedo (789 ng/g lipid) along the Ouémé River [3].

Residue levels of pp'-DDD in the aquatic species collected in the Kiti River were lower than in fish collected from Abidjan markets and fishing areas [3]. Isomers and metabolites of DDT and $\alpha$-endosulfan were identified in Chrysichtys auratus collected at collected in the Ouémé river at Lowé but only DDD was identified in the same fish species from Abidjan. Pesticide residue levels in fish from the Kiti River were lower than in fish from Lake Qarun in Egypt that contained $5 D D T$ concentrations of 2-68 ng/g fresh weight [4]. Similar levels were also reported for fish from the Densu Basin in Ghana [5]. Also pesticide levels in fish from Lake Taabo, Cote D'Ivoire, were higher than the ones found in our study with average levels of 95124 and 104-144 ng/g dry weight for EDDT and $\Sigma$ endosulfan in two different fish species and a species of prawn [6]. These values correspond with concentrations on a lipid basis of 3285-8990 and 5000-8390 ng/g lipid, respectively. Similar levels were 
also reported for $\Sigma$ DDT residues in fish from Lagos Lagoon in Nigeria [7], from the Etsii and Fosu lagoon in Ghana [8], and from various streams of the Cauvery River in India [9]. pp'-DDT and endosulfan residue levels in fish from the Kiti River were in the same range as concentrations reported for fish from the Densu River basin in Ghana [20]. Concentrations of DDE and endosulfan in Cardiosoma armatum from the Kiti River were below values reported for the crayfish Procambarus clarkii from Lake Naivaska in Kenya [1].

\section{Pesticide residues in bean leaves}

The presence of DDT and its metabolites at fairly high levels in bean leaves from all four locations (Table 4) suggests illegal use in the area of this pesticide, which was banned in 1970. This is confirmed by the dominance of DDT in the EDDT concentrations $[8,11,12]$. In all cases DDT levels were as high as or even higher than the levels of the metabolites DDE and DDD. Concentrations reported for beet roots, onions and potatoes from organic farming in Egypt were 0.23-0.66, 1.78-2.82, 0.600.84 and $0.30-0.70 \mu \mathrm{g} / \mathrm{kg}$ fresh weight for endosulfan, $\Sigma$ DDT, lindane and $\Sigma$ drins, respectively [4]. Assuming a dry weight content of 10 and $20 \%$ for onions and potatoes, respectively, these levels correspond with endosulfan, $\mathrm{DDDT}$, lindane and $\Sigma$ drins concentrations of 1.2-6.6, 8.9-28.2, 3.0-8.4 and 1.5-7.0 $\mu \mathrm{g} / \mathrm{kg}$ dry weight, respectively. $\Sigma \mathrm{DDT}, \Sigma \mathrm{HCH}$ and $\Sigma$ drin levels in vegetables, including long beans, from Cambodja were in same range as the ones found in this study [1]. A rather wide range of pesticide concentrations was found in Caspsicum annuum collected from Nigerian markets: $\mathrm{HCH}$ residues dominated with levels as high as $1450-2340 \mu \mathrm{g} / \mathrm{kg}$, while pp'-DDT and pp'-DDE levels were 64-99 and 7-105 $\mu \mathrm{g} / \mathrm{kg}$, respectively [2]. Also in lettuce from urban markets and vegetable sellers in Ghana, higher lindane, endosulfan and DDT residue levels were found [3]. This shows that pesticide residues are still quite commonly found in vegetables from Africa and that the Dridji region is no exception to this.

\section{Pesticide exposure risks}

The current study showed that pesticide exposure of people consuming fish from the Dridji River is fairly limited (Table 5), while consuming bean leaves may pose a considerable risk (Table 6). This in fact was surprising as the investigated pesticides are known for their tendency to accumulate along the food chain and, therefore, were expected to be found at higher levels in fish than in plants. The results of this study suggest that the investigated pesticides are still in use in agriculture in Bénin, which may have caused the higher exposure through vegetable consumption compared to consuming aquatic species. This seems especially the case for dieldrin that contributed most to the risk of pesticides found in bean leaves as can be seen from its high residue levels compared to the TDI (Table 4). Since the pesticide levels found in our study were in the same range as levels found in other (African) countries, the results of this study may also be indicative for the entire region in Africa. This suggests there may be a risk for the local population due to the consumption of bean leaves. This risk may be higher when additional exposure to pesticides from other sources might be involved, for example, in case of farmers being exposed when spraying the pesticides. It is recommended to perform further targeted research to 


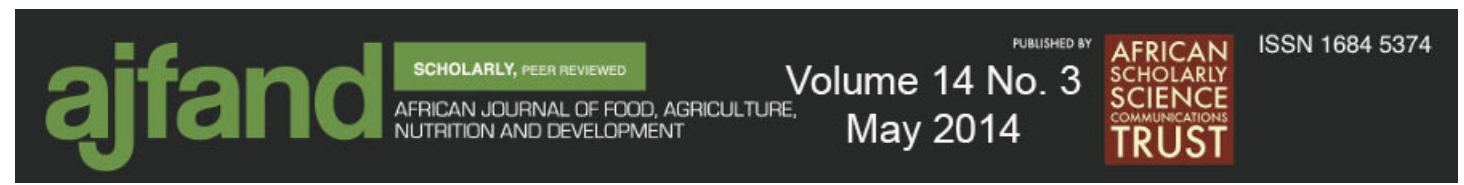

determine exposure and potential public health risks of pesticides and other pollutants (including nitrate and nitrite) in the Dridji region.

\section{CONCLUSIONS}

Sediment, aquatic organisms and especially vegetables from the Dridji cotton growing area in Bénin were contaminated with chlorinated pesticides. The presence of DDT, its metabolites and $\alpha$-endosulfan in sediment, fish and bean leaves indicates earlier as well as continued use of synthetic pesticides in the Dridji area. Pesticide levels in fish were low and not posing a risk to the local population. Pesticide levels in bean leaves, however, were much higher and may pose a risk for the health of humans living in the cotton production area. This risk may be further enhanced by the river water quality, with high levels of nitrite further increasing the potential health risk to the local population. 


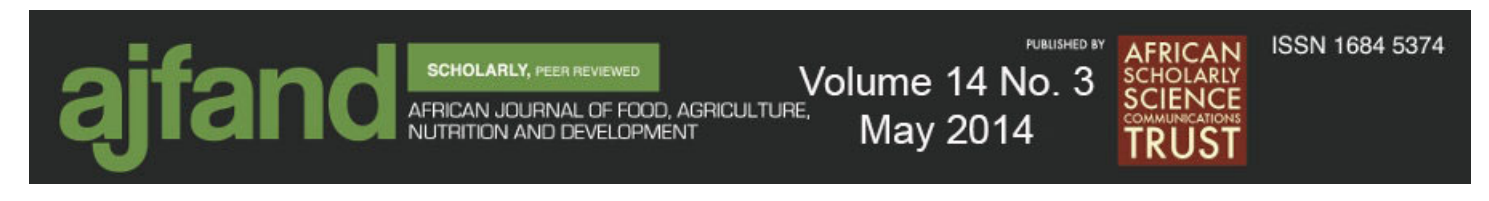

Table 1: Properties of sediment from different sites along the Kiti River in the Dridji area in the Republic of Bénin

\begin{tabular}{|c|c|c|c|c|c|c|c|c|c|c|c|}
\hline Area & $\begin{array}{l}\text { Clay } \\
(<8 \mu \mathrm{m})\end{array}$ & $\begin{array}{l}\text { Fine silt } \\
(8-32 \mu \mathrm{m})\end{array}$ & $\begin{array}{l}\text { Large silt } \\
(32-64 \mu \mathrm{m})\end{array}$ & $\begin{array}{l}\text { Fine sand } \\
(64-250 \mu \mathrm{m})\end{array}$ & $\begin{array}{l}\text { Coarse sand } \\
\text { (250-2000 } \mu \mathrm{m})\end{array}$ & $\sum$ (clay and silt) & $\sum$ sand & \% org matter & \% C & $\% \mathrm{~N}$ & $\mathrm{C} / \mathrm{N}$ ratio \\
\hline DK1* & 4.5 & 9.60 & 20.5 & 8.77 & 55.6 & 34.6 & 64.4 & 5.2 & 2.46 & 0.22 & 11.4 \\
\hline DK2 & 4.7 & 12.6 & 63.2 & 8.27 & 10.4 & 80.5 & 18.7 & 2.3 & 1.27 & 0.11 & 11.6 \\
\hline DK3 & 5.3 & 9.10 & 74.6 & 8.55 & 0.80 & 89.0 & 9.35 & 4.6 & 1.37 & 0.11 & 12.3 \\
\hline DK4 & 4.5 & 13.9 & 32.6 & 8.20 & 39.1 & 51.0 & 47.3 & 4.0 & 1.73 & 0.16 & 11.1 \\
\hline DK5 & 5.0 & 13.4 & 71.0 & 8.20 & 2.40 & 89.0 & 10.5 & 3.0 & 1.47 & 0.14 & 10.7 \\
\hline DK6 & 4.8 & 18.5 & 42.7 & 7.67 & 25.8 & 66.0 & 33.5 & 6.5 & 2.53 & 0.20 & 12.7 \\
\hline
\end{tabular}

*mean of two replicates 


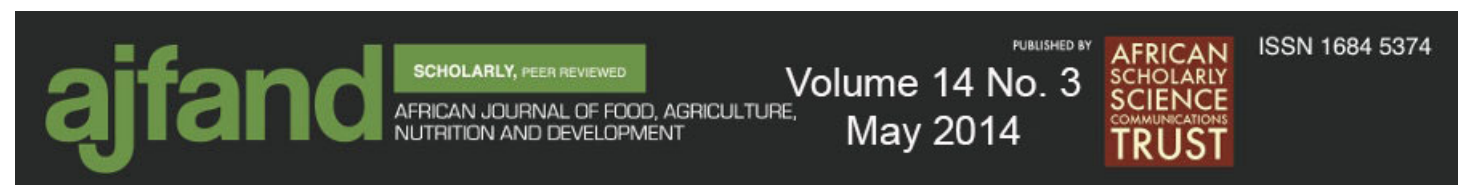

Table 2: Pesticide residue levels (ug/kg dry weight) in sediments from different sites along the Kiti River in the Dridji area in the Republic of Bénin

\begin{tabular}{lcc}
\hline Locations & pp'-DDE & pp'-DDT \\
\hline DK1 & 2.0 & $<1.0$ \\
DK2 & 0.8 & $<1.0$ \\
DK3 & $<1.0$ & $<1.0$ \\
DK4 & $<1.0$ & $<1.0$ \\
DK5 & $<1.0$ & $<1.0$ \\
DK6 & 2.1 & 5.1 \\
\hline
\end{tabular}

Table 3: Pesticide residues (in $\mathrm{ng} / \mathrm{g}$ lipid) in aquatic species collected from the Kiti River in the Dridji area in the Republic of Bénin

\begin{tabular}{|c|c|c|c|c|c|c|c|c|}
\hline \multirow[t]{2}{*}{ Species } & op'- & pp’- & pp’- & op’- & pp’- & $\sum \mathrm{DDT}$ & $\alpha$-endo & \multirow[t]{2}{*}{ \%lipid } \\
\hline & DDE & DDE & DDD & DDT & DDT & & & \\
\hline Clarias ebriensis & $<3$ & 163 & 45 & $<3$ & 6 & 214 & 31 & $4.2 \%$ \\
\hline Clarias gariepinus & $<5$ & 403 & 95 & 6 & 11 & 515 & 75 & $4.6 \%$ \\
\hline Bufo regularis & $<10$ & 68 & $<23$ & $<10$ & $<10$ & 68 & 42 & $2.5 \%$ \\
\hline Xenopus muelleri & $<6$ & 109 & $<14$ & $<6$ & $<6$ & 109 & 44 & $2.8 \%$ \\
\hline Cardiosoma armatum & $<5$ & 23 & $<23$ & $<5$ & $<5$ & 23 & 27 & $2.0 \%$ \\
\hline
\end{tabular}




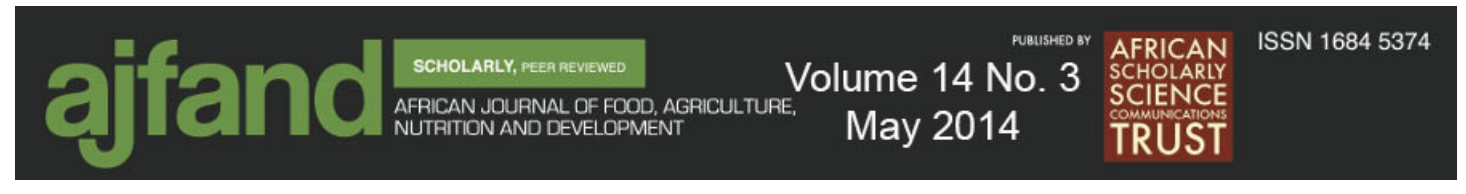

Table 4: Pesticide residues (in $\mu \mathrm{g} / \mathrm{kg}$ dry weight) in bean leaves collected from two locations, in duplicate, in the Dridji region in the Republic of Bénin

\begin{tabular}{|c|c|c|c|c|c|c|c|c|c|c|c|c|}
\hline Location & op'-DDE & pp'-DDE & op'-DDD & pp'-DDD & op'-DDT & pp'-DDT & $\sum \mathrm{DDT}$ & $\begin{array}{l}\alpha \text {-endo- } \\
\text { sulfan }\end{array}$ & dieldrin & lindane & Hcbenz & Hepta \\
\hline Kindogon 1 & $<2$ & 70 & 19 & 54 & 49 & 82 & 274 & 23 & $<9$ & $<9$ & 3 & $<2$ \\
\hline Kindogon 2 & 7 & 123 & 53 & 116 & 88 & 165 & 552 & 28 & 12 & 10 & 3 & $<2$ \\
\hline Daanonkpota 1 & $<2$ & 143 & 90 & 126 & 111 & 250 & 720 & 106 & 20 & $<6$ & 3 & 7 \\
\hline Daanonkpota 2 & $<2$ & 205 & 135 & 357 & 252 & 402 & 1351 & 210 & 32 & 90 & $<2$ & $<2$ \\
\hline
\end{tabular}

$\alpha$-endo is $\alpha$-endosulfan; Hcbenz = hexachlorobenzene; Hepta=Heptachlor. 


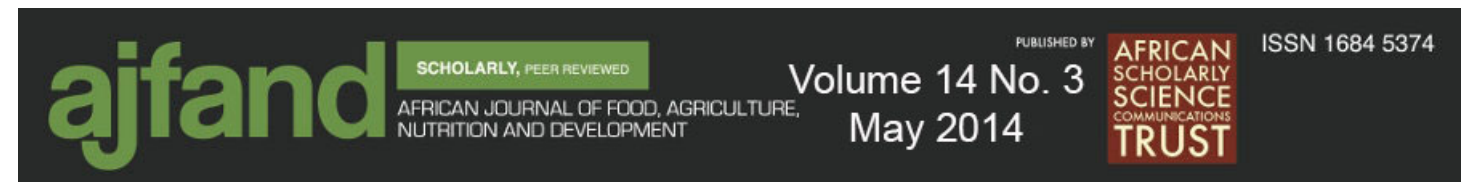

Table 5: Estimation of the potential risk of pesticide intake by the consumption of fish, amphibians or crabs from the Kiti River for the local population of the Dridji region in the Republic of Bénin

\begin{tabular}{llllll}
\hline & $\begin{array}{l}\text { Species } \\
\text { Clarias } \\
\text { ebriensis }\end{array}$ & $\begin{array}{l}\text { Clarias } \\
\text { gariepinus }\end{array}$ & Bufo regularis & $\begin{array}{l}\text { Xenopus } \\
\text { muelleri }\end{array}$ & $\begin{array}{l}\text { Cardiosoma } \\
\text { armatum }\end{array}$ \\
\hline Species meat & 4.7 & 5.0 & 1.45 & 2.13 & 4.0 \\
(dry weight) & $4.2 \%$ & $4.6 \%$ & $2.5 \%$ & $2.8 \%$ & $2.0 \%$ \\
Lipid content & $4.2 \%$ & & & \\
\hline
\end{tabular}

Pesticide concentration in aquatic species (ng/g lipid)

\begin{tabular}{lccccc}
\hline$\Sigma$ DDT & 214 & 515 & 68 & 109 & 23 \\
$\alpha$-endosulfan & 31 & 75 & 42 & 44 & 27 \\
\hline
\end{tabular}

Daily intake with one fish by an adult person of $60 \mathrm{~kg}$ (ng/kg body weight)

\begin{tabular}{llllll}
\hline$\Sigma$ DDT & 0.70 & 2.0 & 0.041 & 0.11 & 0.031 \\
$\alpha$-endosulfan & 0.10 & 0.29 & 0.025 & 0.044 & 0.036 \\
\hline$\Sigma$ Toxic units & 0.000087 & 0.00025 & 0.00000083 & 0.000018 & 0.0000091
\end{tabular}

Summed toxic units were obtained by relating Daily Intakes to the Tolerable Daily Intakes defined by WHO [2] of 10,000 and 6,000 ng/kg body weight/day for $\Sigma$ DDT and Endosulfan, respectively. 


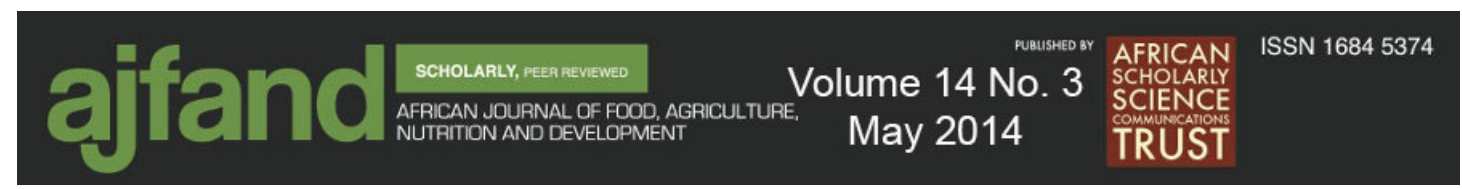

Table 6: Estimation of the potential risk of pesticide intake by bean leaf consumption for the local population of the Dridji region in the Republic of Bénin

\begin{tabular}{|c|c|c|c|c|c|c|}
\hline & $\Sigma$ DDT & $\begin{array}{l}\text { a-endo- } \\
\text { sulfan }\end{array}$ & dieldrin & lindane & $\begin{array}{l}\text { Hexachloro- } \\
\text { benzene }\end{array}$ & \\
\hline $\begin{array}{l}\text { Tolerable daily } \\
\text { intake ( } \mu \mathrm{g} / \mathrm{kg} / \text { day) }\end{array}$ & 10 & 6 & 0.1 & 5 & 0.2 & \\
\hline $\begin{array}{l}\text { Residue tolerance } \\
\text { in plant material } \\
(\mu \mathrm{g} / \mathrm{kg})\end{array}$ & 6000 & 3600 & 60 & 3000 & 120 & \\
\hline \multicolumn{6}{|c|}{ Pesticide residue level in bean leaves $(\mu \mathrm{g} / \mathrm{kg})$} & $\Sigma \mathrm{TU}$ \\
\hline Kindogon 1 & 274 & 23 & 0 & 0 & 3 & 0.077 \\
\hline Kindogon 2 & 545 & 28 & 12 & 10 & 3 & 0.33 \\
\hline Danonkpota 1 & 720 & 106 & 20 & 0 & 3 & 0.51 \\
\hline Danonkpota 2 & 1556 & 210 & 32 & 90 & 0 & 0.88 \\
\hline
\end{tabular}

Tolerated residue levels in bean leaves calculated assuming a consumption of $100 \mathrm{~g}$ dry weight/day by an adult person weighing $60 \mathrm{~kg}$, using Tolerable Daily Intake values established by WHO [2]. Summed toxic units ( $\Sigma T U)$ were obtained by relating pesticide residue levels measured in the bean leaves at four different locations with the tolerated residue levels and summing the resulting TU values for the different pesticides measured in each crop. 


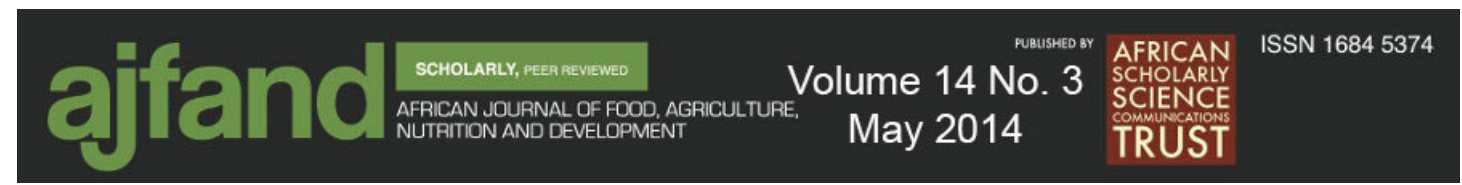

\section{REFERENCES}

1. Okoumassoun LE, Brochu C, Deblois C, Apkonan S, Marion M, Averill-Bates D and $\mathbf{F}$ Denizeau Vitellogenin in tilapia male fishes exposed to organochlorine pesticides in Ouémé River in Republic of Benin. Sci Total Environ 2002; 299: 163172.

2. Yehouenou A, Pazou E, Boko M, Van Gestel CAM, Ahissou H, Akpona S, Van Hattum B, Swart K and NM Van Straalen Organochlorine and Organophosphorous pesticide residues in the Ouémé River catchment in the Republic of Benin. Environ. Int. 2006; 32: 616-623.

3. Yehouenou A, Pazou E, Lalèyè P, Boko $M$, Van Gestel CAM, Ahissou H, Akpona S, Van Hattum B, Swart K and NM Van Straalen Contamination of fish by organochlorine pesticide residues in the Ouémé River catchment in the Republic of Benin. Environ. Int. 2006; 32: 594-599.

4. WHO Chemical Fact Sheets of the International Programme on Chemical Safety (ICPS) of the World Health Organization (WHO), Geneva. 2004, www.who.int/entity/water_sanitation_health/dwq/en/gdwq3_12.pdf $\quad$ (consulted $9^{\text {th }}$ December 2012).

5. Konert $\mathbf{M}$ and $\mathbf{J}$ Vandenberghe Comparison of laser grain size analysis with pipette and sieve analysis: A solution for the underestimation of the clay fraction. Sedimentology 1997; 44: 523-535.

6. Pandey P, Khillare PS and K Kumar Assessment of organochlorine pesticide residues in surface sediments of river Yamuna in Delhi, India. J. Environ. Prot. 2011; 2: 511-524.

7. Malik A, Ojha $\mathbf{P}$ and KP Singh Levels and distribution of persistent organochlorine pesticide residues in water and sediments of Gomti River (India) a tributary of Ganges River. Environ. Monit. Assess. 2009; 148: 421-435.

8. Darko G, Akoto O and C Oppong Persistent organochlorine pesticide residues in fish, sediments and water from Lake Bosomtwi, Ghana. Chemosphere 2008; 72: 2124.

9. Musa S, Wageni Gichuki J, Okoth Raburu $\mathbf{P}$ and $\mathbf{C}$ Mulandra Aura Organochlorine and organophosphorus pesticide residues in water and sediment from Yala/Nzoia River within Lake Victoria basin, Kenya. J. Ecol. Nat. Environ. 2011; 3: 392-399.

10. Bhattacharya B, Sarkar SK and N Mukherjee Organochlorine pesticide residues in sediments of a tropical mangrove estuary, India; implications for monitoring. Environ. Int. 2003 ; 29: 587-592.

11. Gitahi SM, Harper DM, Muchiri SM, Tole MP and RN Ng'ang'a Organochlorine and organophosphorus pesticide concentrations in water, sediment, and selected organisms in Lake Naivasha (Kenya). Hydrobiologia 2002; 488: 123-128. 
12. Dem SB, Cobb JM and DE Mullins Pesticide residues in soil and water from four cotton growing areas of Mali, West Africa. J. Agric. Food Environ. Sci. 2007; 1: 1-12.

13. Biego GHM, Yao KD, Ezoua $\mathbf{P}$ and LP Kouadio Assessment of organochlorine pesticides residues in fish sold in Abidjan markets and fishing sites. Afr. J. Food Agric. Nutr. Develop. 2010; 10: 2305-2323.

14. Mansour SA Persistent organic pollutants (POPs) in Africa: Egyptian scenario. Human Exp. Toxicol. 2009; 28: 531-566.

15. Afful S, Anim AK and Y Serfor-Armah Spectrum of organochlorine pesticide residues in fish samples from the Densu Basin. Res. J. Environ. Earth Sci. 2010; 2: 133-138.

16. Roche H, Tidou A and A Persic Organochlorine pesticides and biomarker responses in two fishes Oreochromis niloticus (Linnaeus, 1758) and Chrysichthys nigrodigitatus (Lacepède, 1803) and an invertebrate, Macrobrachium vollenhovenii (Herklot, 1857), from the Lake Taabo (Côte d’Ivoire). J. Appl. Sci. 2007; 7: 3860-3869.

17. Adeyemi D, Ukpo G, Anyakora C and JP Unyimadu Organochlorine pesticide residues in fish samples from Lagos Lagoon, Nigeria. Am. J. Environ. Sci. 2008; 4: 649-653.

18. Essumang DK, Togoh GK and L Chokky Pesticide residues in water and fish (Lagoon tilapia) samples from lagoons in Ghana. Bull. Chem. Soc. Ethiopia 2009; 23: 19-27.

19. Begum A, Harikrishna S and I Khan A survey of persistant organochlorine pesticides residues in some streams of the Cauvery River, Karnataka, India. Int. J. Chemtech Res.2009; 1: 237-244.

20. Fianko JR, Donkor A, Lowor ST, Yeboah PO, Glover ET, Adom T and A Faanu Health risk associated with pesticide contamination of fish from the Densu River basin in Ghana. J. Environ. Prot. 2011; 2: 115-123.

21. Wang HS, Sthiannopkao S, Dub J, Chen ZJ, Kim KW, Yasin MSM, Hashim JH, Wong CKC and MH Wong Daily intake and human risk assessment of organochlorine pesticides (OCPs) based on Cambodian market basket data. J. Haz. Mat. 2011; 192:1441-1449.

22. Benson NU and AI Olufunke Assessment of contamination by organochlorine pesticides in Solanum lycopersicum L. and Capsicum annuum L.: A market survey in Nigeria. Afr. J. Environ. Sci. Technol. 2011; 5: 437-442.

23. Amoah P, Drechsel P, Abaidoo RC and WJ Ntow Pesticide and pathogen contamination of vegetables in Ghana's urban markets. Arch. Environ. Contam. Toxicol. 2006; 50: 1-6. 